\title{
HOW THE SOIL MOVES UPWARD IN THE OLIVE ORCHARDS OF NW SYRIA: SUSTAINABILITY ANALYSIS OF A LOCAL INNOVATION
}

\author{
Liesbeth Colen ${ }^{1 *}$, Francis Turkelboom ${ }^{2 \dagger}$, Sarah Van Steenwinkel ${ }^{3}$, Kasem Al Ahmed ${ }^{2}$, Jozef Deckers ${ }^{3}$, Jean Poesen ${ }^{3}$ \\ ${ }^{1}$ LICOS, Faculty of Business and Economics, Katholieke Universiteit Leuven (KU Leuven), Leuven, Belgium \\ ${ }^{2}$ International Center for Agricultural Research in Dry Areas (ICARDA), Aleppo, Syria \\ ${ }^{3}$ Department of Earth and Environmental Sciences, Katholieke Universiteit Leuven (KU Leuven), Leuven, Belgium
}

Received: 30 April 2013; Revised: 16 October 2013; Accepted: 17 October 2013

\begin{abstract}
This paper analyses a local innovation in response to intense soil degradation in olive orchards of north-west Syria. Farmers developed a practice consisting of quarrying red clayey soil in valley bottoms and applying this soil to hillslope olive orchards with heavily degraded calcareous soils. A biophysical, economic and social analysis of the practice of soil application identified the opportunities and risks of this innovative soil management technique. On the basis of a pairwise comparison of nine adjacent treated and nontreated orchard plots, soil applications were found to increase soil depth by $36 \%$, soil water availability by $28 \%$ and total available soil nutrients: potassium ( $+45 \%)$, nitrogen $(+12 \%)$ and phosphorus $(+6 \%)$. Olive yield increased by about $40 \%$. A cost-benefit analysis found this practice to be economically viable within a large geographical area, and farmers scored the practice higher than alternative methods. A socio-economic analysis revealed its widespread adoption among different farmer types. The positive results of soil applications at the farm level explain its fast adoption. However, potential risks - including the further depletion of soil resources and the transfer of soil-borne diseases - limit the long-term sustainability of this locally developed practice. Copyright () 2013 John Wiley \& Sons, Ltd.
\end{abstract}

KEY WORDS: local innovation; soil management; soil degradation; olive orchards; Syria

\section{INTRODUCTION}

Land degradation due to intense soil erosion and nutrient depletion is considered to be an important threat to agricultural development and poverty alleviation in many developing countries (Scherr, 1999). The poor adoption of various soil and water conservation techniques has led conservationists to a more holistic approach, which reconciles natural and social sciences (McDonald \& Brown, 2000), and to the incorporation of valuable local knowledge and innovations that land users themselves continuously develop and adapt in order to cope with their changing environment (Critchley et al., 1994; Reed et al., 2013). However, not all indigenous strategies offer sustainable solutions, and local knowledge is primarily context dependent (Reed et al., 2013) which makes it only applicable under specific local conditions. Therefore, they should only be promoted after a critical analysis.

This paper analyses a local innovation, which has been developed in response to intense land degradation in hillslope olive orchards of north-west Syria. Land degradation is a severe problem in most Mediterranean countries. The combination of dry and hot summers, erosive rains,

\footnotetext{
* Correspondence to: Liesbeth Colen, LICOS, Faculty of Business and Economics, Katholieke Universiteit Leuven (KU Leuven), Waaistraat 6 bus 3511, BE3000 Leuven, Belgium.

E-mail: liesbeth.colen@kuleuven.be

${ }^{\dagger}$ Present address: Research Institute for Nature and Forest Research (INBO) Brussels, Belgium
}

mountainous terrain, low tree density and frequent tillage have generally resulted in low soil fertility and strongly eroded terrains (Milgroom et al., 2007; Cerdà et al., 2010). Moreover, the rapid population growth in this region continues to increase pressure on land resources (Zdruli, 2012).

During the last decades, Syrian olive cultivation expanded into marginal areas, including the fragile mountain lands in Afrin. Intense soil tillage and lack of soil conservation measures are leading to severe erosion and therefore to a strong decline in soil depth and soil fertility. Hoorelbeke (2005) estimated that olive cultivation on these slopes has led to a severe decline in soil depth $(-31 \%)$ and soil fertility parameters (ca. $-50 \%$ ) compared with undisturbed reference forest land. Bruggeman et al. (2005) found on experimental plots in Afrin with a slope gradient between $25 \%$ and $45 \%$ an average soil loss of $50 \mathrm{Mg} \mathrm{ha}^{-1} \mathrm{y}^{-1}$ by water and tillage erosion with conventional farm management practices. In the same region, Barneveld et al. (2009) estimated that on a slope of $25 \%$ with five annual passages of up-and-down ploughing (which is not exceptional in the region) annual soil loss is about $80 \mathrm{Mg} \mathrm{ha}^{-1} \mathrm{y}^{-1}$. This represents a decline of soil depth of $7 \mathrm{~mm} \mathrm{y}^{-1}$ in the sediment delivering part of field plots. Although two-third of the farmers in Afrin attribute the declining yield trend to soil erosion, farmers barely apply soil conservation measures and continue frequent up-and-down ploughing (Hoorelbeke, 2005).

To cope with this heavily degraded environment, olive farmers have developed an original land management technique that they refer to as 'adding red soil on to white soil' 
(in Arabic: Taghir at-turbe hamra al abiad). The practice consists of digging up 'red-coloured' clayey limestonederived soil and applying it around olive tree stems on hillslopes that have 'white-coloured', shallow and heavily degraded marl-derived soils (Figure 1).

Applying a layer of sand or gravel on agricultural land to improve crop productivity has been reported in various parts of the world, for example, Nachtergaele et al. (1998) for Switzerland, Li (2003) for northwest China, Tejedor et al. (2003) for Spain and Nyssen et al. (2000) \& Gebreyohannes et al. (2012) for Ethiopia. However, few studies describe the application of soil material on to degraded agricultural land, similar to the practice observed in NW Syria. Vogt (1970) \& Brenot (2007) reported that already since medieval times, farmers in wine-producing regions of France collected deposited sediments (colluvium) at the foot of sloping vineyards and transported this material back to the hillslopes in order to maintain a certain soil thickness. Similar practices in vineyards of the Mosel region in Germany were reported by Richter (pers. com.). He et al. (2007) reported that farmers in the Sichuan Hilly Basin of China collect sediment trapped in ditches and return it to the fields. Papiernik et al. (2009) described how north-American farmers move soil from areas of topsoil accumulation to areas of topsoil depletion in order to remediate eroded landforms. Although all these studies report soil applications on (degraded) cropland, the practice of soil application as observed in Syria is different in that the applied material is taken from locations with different soil characteristics than the original soil. Hence, the practice aims at increasing soil depth and at altering soil characteristics at the same time. Also in other places in the Mediterranean, the best soils from the valley bottoms have been transported to the slopes or used when constructing agricultural terraces (Cerdá, pers. com.). Yet, none of these practices have been formally described and analysed. This paper is the first to provide a scientific analysis of the process of soil application and its overall sustainability.

Given the limited scientific literature on soil applications, the first objective of this study was to document the origin, functioning and evolution of this locally developed strategy of soil application. Second, we aim to assess its overall sustainability by analysing the biophysical, economic and social aspects of this practice.

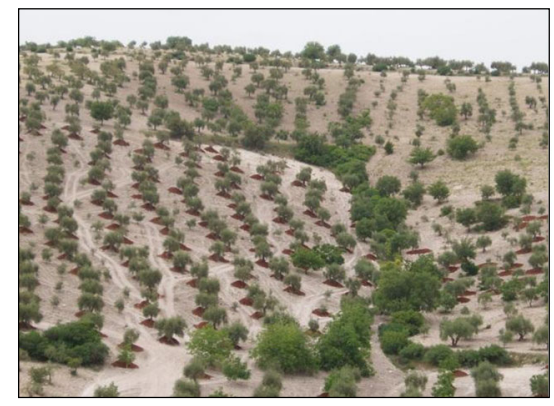

\section{MATERIAL AND METHODS}

To assess the sustainability of the practice of soil application, different research methods and sources of knowledge were used, including biophysical measurements, stakeholder interviews and socio-economic data analysis. All information was collected between August and November 2006.

\section{Study Area and Description of the Practice of Soil Application}

The study area is Afrin district, situated in NW Syria and covering about $2,000 \mathrm{~km}^{2}$. Afrin is one of Syria's main regions of olive production, and $85 \%$ of Afrin's households depend on olive cultivation (Extension Office Afrin, pers. comm.).

Two broad types of soils are prevalent in the region. Farmers refer to these soil types as 'white' and 'red' soils and use this terminology also to discuss the practice of soil applications (adding red soil on to white soil). The red soils are iron-rich limestone-derived soils that are located in the valley bottoms. They have a high content of swelling clays, poor drainage and produce cracks upon drying. The red colour is due to summer dehydratation of free iron oxyhydroxides. De Pauw et al. (2006) classified these soils as Chromic Vertisols and Chromi-Calcaric Cambisols (WRB (IUSS Working Group), 2006). White soils are found on most slopes. These are severely eroded, nutrient-poor soils that retain less water compared with the soils in the valley bottom. The white soils are derived from chalky limestone or marl, and in several places, long lasting erosion has exposed the parent material and hardly any soil material is left. They are classified as Calcaric-Hyperskeletic Leptosol (Cools et al., 2003). For simplicity, we will use the local classifications referring to the soil colour.

The practice of soil application starts with the excavation of soil using a bulldozer at a 'soil quarry'. Figure 2 illustrates the location of the largest soil quarries in Afrin in 2006. Soil is extracted from two different types of quarries. First, the majority originated from construction sites in the city of Afrin, which is located in the plains where red soils prevail. When a building is constructed, soil needs to be excavated and instead of dumping the excavated soil - building contractors allow farmers to take the soil to their fields, sometimes requiring a small payment. Second, soil quarries in cropland are locations where red soil is quarried in agricultural land, with

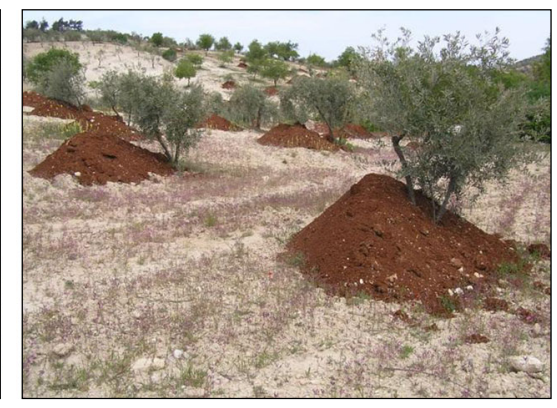

Figure 1. Recently applied red soil on to white soils in sloping olive orchards, Afrin district, NW Syria, 2006. This figure is available in colour online at wileyonlinelibrary.com/journal/ldr. 


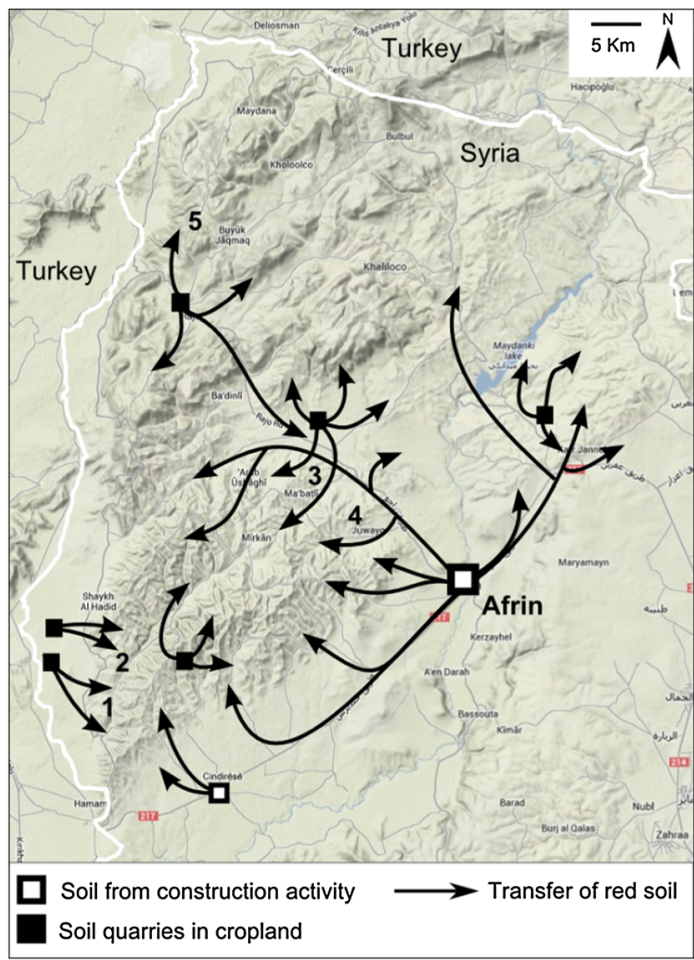

Figure 2. Map of Afrin with main flows of red soil, extracted from valley bottoms, to the hilly olive orchards with white soils in 2006. Numbers indicate the villages of (1) Inqalah, (2) Sannarah, (3) M'abathly, (4) Khadra and (5) Makanli. Source base map is the World Terrain Base (Esri, 2009). This figure is available in colour online at wileyonlinelibrary.com/journal/ldr.

the purpose of applying the soil to the hillslopes. At the time of research, eight of such large red soil quarries were identified in the region of Afrin, some in unused agricultural land, others in olive orchards or fields with other crops. Usually, this soil is sold from one farmer or land owner to another farmer. In few cases, farmers dug up soil between the olive trees from their own valley-bottom orchard.

The soil is transported to the olive orchards on the hillsides, either by the farmer himself (if he owns a tractor and trailer) or by a transporter. The trailer is emptied mechanically, and usually, one trailer of soil per olive tree $\left(2.5 \mathrm{~m}^{3}\right)$ is piled around the tree stem. Subsequent tillage operations (usually 2-6 times per year) then gradually spread the applied red soil and mix it with the original white soil.

\section{Origin of the Practice}

The practice of soil application originated in the period 1990-1995, when a few Afrin farmers started experimenting with applying red soil from the valley bottoms on degraded white soils of the hillslopes in order to improve the yield. The idea was probably derived from the older and 'opposite' soil application strategy that was observed in the neighbouring district Idleb, where white soil was added on to red orchards in the valleys to improve water holding characteristics and to prevent cracks during the dry season. As estimated and described further, the adoption of the practice has spread remarkably fast over the following years, especially compared with the almost nonadoption of conventional soil conservation measures in the region.

\section{Soil Analysis and Yield Estimation}

In order to estimate the impact of soil application on soil characteristics and yields, sites were selected where trees with and without soil applied could be found next to each other and such that - except for the soil applications - they would be perfectly comparable. Parts of adjacent orchard plots with the same parent material, slope aspect, rainfall exposure, olive variety, age of trees, moment within production cycle and orchard management were selected, the only difference being that in the 'treated' part soil was applied 2-3 years earlier; whereas in the adjacent 'nontreated' part, no soil was applied. In total, nine such pairs of treated and untreated orchard plots were selected. For eight out of nine pairs, the treated and untreated plots were part of the same orchard with the same management history except that the farmer applied soil to some but not all of the trees. For the ninth pair, past management practices of the two farmers were recorded in detail and were found to be comparable. At each of the 18 selected sites (nine with and nine without treatment), three trees were selected. For each of the selected trees, soil analyses and olive yield measurements were performed. By ensuring that all locational, soil, tree and management characteristics are equal within each pair, the impact of applying soil (the treatment) on soil characteristics and olive yield can be estimated as the difference between the paired observations.

\section{Soil analyses}

All the selected plots were in a heavily degraded state, with an average soil depth of only $0.1 \mathrm{~m}$ and a maximum of $0 \cdot 2 \mathrm{~m}$. Below this soil layer, a parent rock was found. Under each canopy of the 54 selected trees, six subsamples were taken of the complete soil layer $(0-0.2 \mathrm{~m})$ and were mixed into one sample.

In addition, a soil sample was taken at eight different soil quarries, in order to assess the original characteristics of the applied soil. Soil samples from the quarries consisted of three subsamples that were mixed into one sample. These subsamples were taken where soil was being removed at the moment of sampling, that is, at a depth varying from 1.5 to $8 \mathrm{~m}$.

The soil samples from the fields and quarries were analysed using standard laboratory procedures. The particle-size distribution was determined using the hydrometer method. Water retained at $33 \mathrm{kPa}$ (field capacity) and at $1,500 \mathrm{kPa}$ (permanent wilting point) was determined using a pressure plate extractor. Soil organic carbon (OC) was quantified using the Walkley-Black wet oxidation method (Nelson \& Sommers, 1982) and converted to soil organic matter content $(\mathrm{OM})$ using $\mathrm{OM}=\mathrm{OC} \times 1.724$ (Van Bemmelen, 1890). Total N, available $\mathrm{P}$ and available $\mathrm{K}$ were determined using the Kjeldahl procedure (Bremmer \& Mulvaney, 1982), Olsen's $\mathrm{NaHCO}_{3}$ method (Olsen et al., 1954) and the ammonium acetate method, respectively (Knudsen et al., 1982). Using paired dependent $t$-tests, the statistical differences in soil parameters between the treated and nontreated parts of the orchards were analysed. 
Olive yield measurements

The impact of soil application on olive yield was assessed using three different methods. Given the biennial bearing of olive (with a large production in 1 year and almost no production in the subsequent year), we only estimated the impact on yield in bearing years.

First, farmers were asked about past olive yields for each of the 18 treated plots that were selected. These recall data were collected for each bearing year, starting from at least 3 years before soil was applied up to the latest harvest (2005). In general, farmers keep a good track of their past yields, especially when experimenting with new practices and had no difficulties recalling the yields. Nevertheless, we must be aware that their reported yields could be potentially biassed when farmers believed we could pass on this information to the revenue office or if they wanted to give a good image of the practice of soil application or of their orchard management in general. Moreover, the difference in olive yield after soil had been applied could be partly due to other factors than the practice of soil application. For example, this difference could be over or underestimated if the years before applying the soil were climatologically more or less favourable than the years after soil was applied. Therefore, this estimate on the basis of farmers' yield records will be used cautiously.

Second, the yield was measured by weighing the olives for each selected tree separately, immediately after harvest (November 2006). Although the aim was to do so for all those pairs of treated and untreated orchards for which 2006 was a bearing year (six out of nine pairs), logistic problems resulted in yield measurements for only three out of the nine selected pairs of treated and untreated orchards (18 trees in total).

A third method consisted of the estimation of the yield for each of the selected trees in those six pairs of treated and untreated orchards that were in a bearing year (36 trees in total) through visual assessment by an olive expert from the Idleb Olive Bureau, just before the harvest took place. The same method was used by Tubeileh et al. (2008). In order to test the accuracy of these expert estimations, the data of the three pairs of orchards where yield could be measured were compared with the estimated yield data. The treatment effect based on expert estimation was found to differ by only $3.5 \%$ on average, and not significantly different from zero from the treatment effect that was actually measured through weighing, suggesting that the expert estimations can be considered sufficiently accurate.

The olive yield measurements and estimates for the latter two methods were statistically analysed using paired dependent $t$-tests.

\section{Socio-economic Data Collection}

The different stakeholders were identified, and 28 farmers, 7 soil transporters, 4 bulldozer owners, 2 building contractors, 7 owners of soil quarries in cropland, 2 agricultural input providers, 7 extension officers and 2 municipality officials from Afrin city were interviewed. Questions focused on the organization and costs of the practice of soil application over the past years, their perceptions regarding its advantages and disadvantages, olive prices, sources of soil and the percentage of farmers in the village having adopted the practice over the past years.

\section{Cost-benefit analysis}

The costs and benefits related to the practice of soil application were identified in order to analyse the economic viability of the practice. The benefit of applying soil is the increase of olive yield in current and future years and is estimated on the basis of the biophysical analysis. The costs of buying, transporting and applying soil are identified on the basis of interviews with the different stakeholders. The net present value (NPV) is calculated as the difference between the present value of all present and future benefits and costs. Future values are discounted at a rate of $15 \%$ per year, which is the discount rate used by International Center for Agricultural Research in the Dry Areas (Consultative Group on International Agricultural Research) for the Syrian rural areas and that is based on the interest rate of the Syrian Agriculture Bank. A positive NPV indicates that it is economically profitable to adopt the practice.

\section{Matrix scoring exercises}

Although economic profitability is a first requirement for adopting a land management practice, farmers must also consider the practice better than alternative techniques (that may also be economically profitable) before they will adopt. Therefore, five villages (Inqalah, Sannarah, M'abathly, Khadra and Makanli; Figure 2) with a considerable adoption level, that is, about $25 \%$ of the farmers applying soil as identified during stakeholders interviews, were selected for a matrix scoring exercise in which the different orchard management practices were compared. In each village, a group of five to seven farmers was gathered. The relevant decision criteria were determined, and then, the different orchard management practices were scored according to these criteria. The results were discussed in group.

\section{Analysis of the determinants of adoption}

In order to understand the socio-economic background of adopters and nonadopters of the practice of soil application, information was collected through individual farmer interviews. A total of 111 farmers - of which 58 farmers had adopted the practice - from 63 villages spread over the entire district were interviewed using a semistructured questionnaire. Information was collected on farmer's characteristics (age, city-based or village-based and whether the farmer works as a transporter), farmers' self-reported wealth (poor/ intermediate/rich), the share of olive cultivation in the farmer's total income, orchard characteristics (distance to Afrin, distance to nearest road and soil depth of his orchards), whether or not the farmer had adopted the practice and - if so - in what year he first applied soil and on farmers' perceptions of the practice of soil application. Most of these interviews were held at the olive mills during the 
harvesting season, where all types of farmers, including adopters and nonadopters, village-based or city-based, rich and poor farmers, could be found while waiting for their olives to be pressed to oil. This ensured an unbiassed selection of farmers for interview. First, a probit regression model was used with a binary dependent variable indicating whether or not the farmer is an adopter. Second, the determinants of early or late adoption were analysed using a linear regression model with the number of years because the farmer first adopted the practice as dependent variable.

\section{RESULTS}

\section{Biophysical Analysis}

On the basis of the soil analyses and yield measurements, the biophysical impact of applying soil was estimated.

\section{Soil characteristics}

Soil sample analysis revealed that, except for potassium, the added soil itself contains less nutrients than the original soil (Table I). As a result, after mixing the applied and original soil, a kilogramme of soil in a treated orchard contains significantly less $\mathrm{P}, \mathrm{N}$ and $\mathrm{OM}$ compared with a kilogramme of soil in untreated orchards and also has a lower available water content.

The applied soil is more 'heavy' (62\% clay), and therefore, applying soil significantly increases the clay content of the topsoil (on average, 32\% for untreated compared to $49 \%$ for treated orchards). The increased clay content of the topsoil after applying red soil is likely to result in decreased soil erodibility (see Torri et al., 1997). On the other hand, in early stages after application, the loose, noncompacted piles are probably more susceptible to erosion. Hence, it is unclear whether the claim that red soil application reduces erosion rate, as was stated by some farmers, is valid. The rate of erosion of the newly applied soil will also affect the duration of the yield increase because of applying soil.

These results indicate that the most important effect of applying soil is not the improvement of nutrient concentrations

Table I. Comparison of properties of the applied red soil and of the topsoil $(0 \cdot 15 \mathrm{~m})$ of untreated and treated orchards

\begin{tabular}{lccc}
\hline Soil characteristics & $\begin{array}{c}\text { Applied } \\
\text { red soil }\end{array}$ & $\begin{array}{c}\text { Untreated } \\
\text { orchard }\end{array}$ & $\begin{array}{c}\text { Treated } \\
\text { orchard }^{\text {a }}\end{array}$ \\
\hline Particle size distribution & 62 & 32 & 49 \\
$\quad$ Clay (\%) & 31 & 41 & 35 \\
$\quad$ Silt (\%) & 9 & 26 & 16 \\
$\quad$ Sand (\%) & & & \\
Soil nutrients & $0 \cdot 6$ & $1 \cdot 7$ & $1 \cdot 3$ \\
$\quad$ Total N (g/kg) & $4 \cdot 3$ & $24 \cdot 8$ & $12 \cdot 8$ \\
Available P (mg/kg) & 241 & $180 \cdot 6$ & $253 \cdot 8$ \\
Available K (mg/kg) & 8 & 34 & 24 \\
Soil organic matter $(\mathrm{g} / \mathrm{kg})$ & 12 & 15 & 13 \\
Available water content (\%) & & & \\
\hline
\end{tabular}

${ }^{a}$ For all soil characteristics, the difference between untreated and treated orchards was found to be significantly different from zero at the $5 \%$ level. (except for the increase in potassium concentration), but rather the net addition of soil volume and nutrients. Adding $2.5 \mathrm{~m}^{3}$ of soil under the canopy of the tree (which has an average diameter of 5-6 $\mathrm{m}$ and corresponds to the main rooting zone) equals to an increase in soil depth of $0.09 \mathrm{~m}$ within the canopy area, and a net addition of nutrients of $1,387 \mathrm{~g} \mathrm{~N}, 10.2 \mathrm{~g}$ available $\mathrm{P}, 572.4 \mathrm{~g}$ available $\mathrm{K}$ and $19 \mathrm{~kg}$ of OM (Table II). The net increase in available soil water content is about 3001.

To assess the beneficial effects in relative terms, we calculated the percentage improvement of soil characteristics for a red soil application of $2.5 \mathrm{~m}^{3}$ on $0.25 \mathrm{~m}$ of a white soil. We use a soil depth of $0.25 \mathrm{~m}$ to obtain a conservative estimate. Note that for most orchards where red soil was applied (including the ones selected for our analysis), soil depth was even lower. It is calculated that applying soil represents an increase of $36 \%$ for soil depth and rooting volume, $11.5 \%$ for total $\mathrm{N}, 5.8 \%$ for available $\mathrm{P}, 45 \%$ for available $\mathrm{K}, 7.9 \%$ for $\mathrm{OM}$ and $28 \%$ for available water content. These numbers indicate that on shallow soils, the application of nutrients and available soil water content are substantial both in absolute and relative terms.

\section{Yield measurements}

The three methods of yield measurements confirmed that applying soil significantly increases the olive yield in the bearing year. Farmers' yield records of the selected plots before and after treatment report an average olive yield of $24 \mathrm{~kg}$ tree ${ }^{-1}$ before treatment, compared to $39 \mathrm{~kg}$ tree ${ }^{-1}$ 3 years after having applied red soil. However, as mentioned before, the estimated increase of $15 \mathrm{~kg} \mathrm{tree}^{-1}$ could be biassed because of climatological differences before and after the treatment or because of biassed reporting.

Expert estimations of the olive yield of the selected trees resulted in an average treatment effect of $12 \mathrm{~kg} \mathrm{tree}^{-1}$ ( $24 \mathrm{~kg}$ for untreated compared to $36 \mathrm{~kg}$ for treated trees).

Table II. Net and relative addition of soil depth and volume, nutrients and available soil water content from applying $2.5 \mathrm{~m}^{3}$ of red soil onto an orchard with original soil depth of $0.25 \mathrm{~m}^{\mathrm{a}}$

\begin{tabular}{llc}
\hline & \multicolumn{2}{c}{ Increase in soil quality by soil addition } \\
\cline { 2 - 3 } & \multicolumn{1}{c}{$\begin{array}{c}\text { Net } \\
\text { addition }\end{array}$} & $\begin{array}{c}\text { Relative addition } \\
\text { (compared to original } \\
\text { soil without soil application) }\end{array}$ \\
\hline Soil characteristics & $+0.089 \mathrm{~m}$ & $+36 \%$ \\
Soil depth & $+2.5 \mathrm{~m}^{3}$ & $+36 \%$ \\
Soil volume & & $+11.5 \%$ \\
Soil nutrients & $+1,387 \mathrm{~g}$ & $+5 \cdot 8 \%$ \\
$\quad$ Total N & $+10 \cdot 2 \mathrm{~g}$ & $+44.9 \%$ \\
Available P & $+572 \cdot 4 \mathrm{~g}$ & $+7.9 \%$ \\
Available K & $+19 \mathrm{~kg}$ & $+28.3 \%$ \\
Soil organic matter & +3001 & \\
Available soil water & & \\
content & &
\end{tabular}

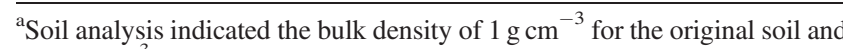
$0.95 \mathrm{~g} / \mathrm{cm}^{-3}$ for the newly applied soil. These numbers are used to convert nutrient concentrations into net and relative addition of nutrients. 
For the three pairs of treated and untreated plots for which actual measurements of olive yield were available, an average treatment effect of $10 \mathrm{~kg}$ tree $^{-1}$ was found $(29 \mathrm{~kg}$ for untreated compared with $39 \mathrm{~kg}$ for treated trees). Overall, our results indicate that applying red soil leads to an average yield increase of $10-15 \mathrm{~kg}_{\text {tree }}-1$, which - given the average yield of 24-29 kg tree ${ }^{-1}$ for untreated trees - corresponds to a relative increase of at least $40 \%$. As farmers reported, this yield increase may be more important on more shallow soils, whereas the effect is likely to be negligible for orchards where soil depth is not a limiting factor.

Note that in exceptionally dry or wet years, the impact of applying soil on olive yield may be slightly different from the yield impact that we estimated, which is based on a period with average rainfall conditions. For example, the increase in available water because of the newly applied soil may be especially crucial in periods of drought. In dry years, yield differences between untreated and treated trees could thus potentially be larger.

Even though the yield estimations are subject to a number of limitations, the results do suggest that soil applications may improve yield considerably.

\section{Socio-economic Analysis}

\section{Evolution of adoption}

Figure 3 illustrates how the practice of soil application increased slowly during the following years and how since 2003 adoption of this practice increased exponentially. It was estimated that in 2006, 640 farmers were applying soil on their hillslope olive orchards, corresponding to $2 \%$ of the estimated 32,000 olive farmers in Afrin and to a total of $230,000-330,000 \mathrm{Mg}$ of red soil.

The level of adoption of the practice is characterized by a large geographical variability. Depending on the village's distance to a soil quarry and the severity of soil degradation, adoption rates vary from $0 \%$ to $30-40 \%$ of olive farmers per village. Figure 2 maps the main soil flows from the valley bottoms to the hillslope orchards in Afrin district.

\section{Cost-benefit analysis}

This section describes the costs and benefits related to soil application at the farm level and analyses whether and under

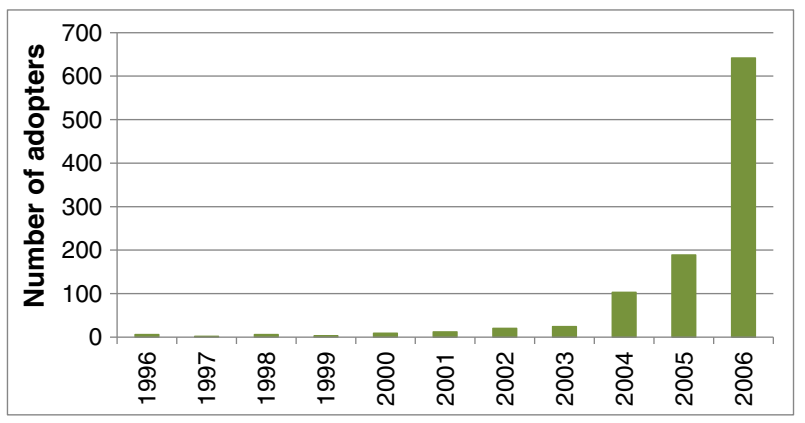

Figure 3. Number of new adopters (i.e. farmers who started to apply red soil on their orchards) per year in Afrin district (1996-2006). For details on the assessment method, see Colen \& Van Steenwinkel (2007). This figure

is available in colour online at wileyonlinelibrary.com/journal/ldr. which conditions the practice of red soil application is a profitable land management strategy. The monetary benefits of applying soil consist of the value of the increase in olive yields in the bearing years of the tree, which was estimated to be $10-12 \mathrm{~kg}$ per tree. The yield effect is assumed to last for 6 years ( 3 bearing years) and is valued at $\$ 0.47$ per $\mathrm{kg}$ of olives, which is based on the average price of olive oil in 2006, average oil content, the fee paid to the olive miller and wages paid to harvesting labourers.

The costs related to applying soil were identified and include the price of red soil paid to the owner of the soil quarry and the cost of hiring someone to transport and to apply the soil by tractor, which consists of a fixed price plus a price per kilometre. Hence, the cost increases rapidly with the distance from the orchard to the source of soil. When a farmer owns a tractor, it is more profitable to organize the transport himself, and we take into account tractor costs, fuel costs and the opportunity cost of his time. On the basis of this information on the present and future benefits and costs of applying soil, the NPV is calculated. We find that for a yield increase of $10 \mathrm{~kg}$ during 3 bearing years, it is profitable to apply soil as long as the orchard is not located more than $26 \mathrm{~km}$ away from the soil quarry (or more than $40 \mathrm{~km}$ if the farmer owns a tractor). This result corresponds well to the observation that of the 58 interviewed farmers that had applied soil, only six had an orchard that was located more than $25 \mathrm{~km}$ away from a soil quarry.

Because the result of the cost-benefit analysis (CBA) is highly dependent on our assumptions regarding the magnitude of the olive yield effect, Figure 4 gives an indication of the sensitivity of our results to these assumptions. This figure illustrates the minimum yield increase that is required for applying soil to be profitable, given a certain distance. For example, if the true yield impact would correspond to $5 \mathrm{~kg}$ per tree instead of $10 \mathrm{~kg}$, it would only be profitable to apply soil for orchards within a radius of $8 \mathrm{~km}$ to the soil quarry. Similarly, if the period of yield increase is shorter than the 3 bearing years (for example, because the newly

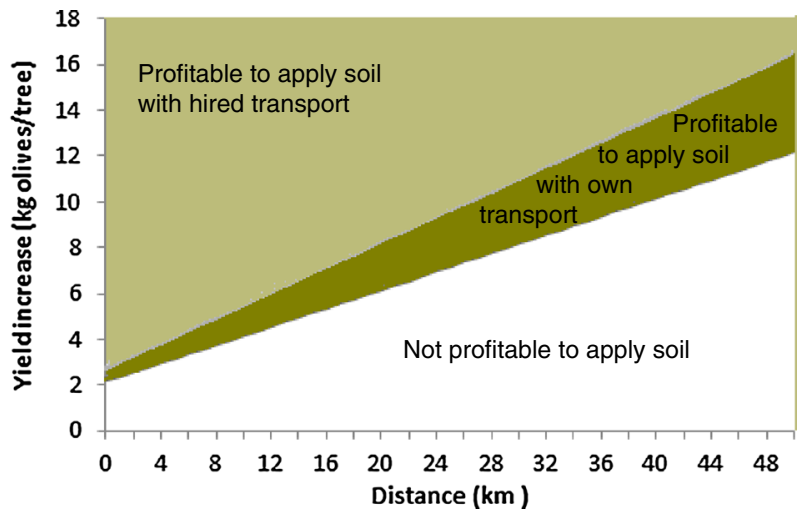

Figure 4. Profitability of applying red soil as a function of the distance to the soil quarry (in $\mathrm{km}$ ) and the yield effect of applying soil (in $\mathrm{kg}$ olives/tree). The grey areas indicate the combinations of yield increase and distance for which applying soil is profitable at the farm level when hiring someone to transport the soil or when the farmers organizes transport himself. This figure is available in colour online at wileyonlinelibrary.com/journal/ldr. 


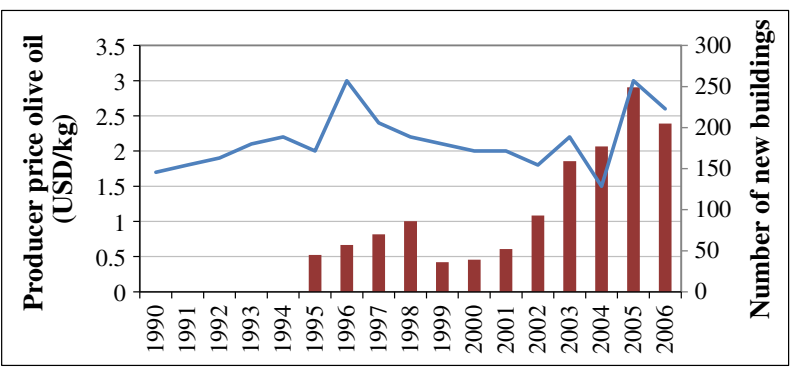

Figure 5. Producer price of olive oil in Afrin ( $\$ / \mathrm{kg}$ ) (line) and number of new buildings constructed in Afrin town (columns) during the period 1990-2006. Sources are statistical records obtained from olive oil traders in Afrin, Idleb Olive Bureau and Afrin Municipality. This figure is available in colour online at wileyonlinelibrary.com/journal/ldr.

applied soil erodes very fast), this would correspond to the practice being profitable within a smaller radius only. For more details and sensitivity analyses of the CBA, reference is made to Colen \& Van Steenwinkel (2007).

Market and contextual factors affecting economic profitability A number of contextual factors contributed positively to the profitability of the practice of soil application and as such have played a crucial role in the remarkable speed of diffusion of the practice. First, after a period of declining olive prices since 1997, the olive price in 2005 was $50 \%$ higher compared with the average price in the previous 5 years (Figure 5), which is at least partly explained by the low olive production in Spain because of drought (Pérez y Pérez \& Barreiro-Hurlé, 2009). Such an increase in olive oil prices corresponds to a parallel shift of the hypotenuse of the "profitability triangle' (Figure 4) upwards and to the left, increasing the set of combinations for which applying soil is profitable. Besides increasing the expected return from olive cultivation, this price hike also increased farmers' revenues, thereby providing farmers with the possibility to invest in their orchards. The high olive oil price in late 2005 coincides indeed with the large increase in adoption of soil applications the next year (Figure 3).

Second, construction of buildings in the city of Afrin has been booming. The expansion of the city into agricultural land increased very fast, and the number of new buildings constructed in Afrin tripled over a 5-year period (2001-2006, Figure 5), providing a continuous supply of easy-available and cheap red soil from these construction sites.
A third factor is the heavily subsidized fuel price in Syria that was in place during the period of research. Given the high share of transportation costs in the total cost of applying soil, the economic profitability would be more geographically limited if fuel would be paid its real price.

Finally, the lack of regulation on whether and where soil can and cannot be excavated gave a free hand for soil quarries to emerge in any place in response to the increasing demand for soil and the increasing price paid for soil. In theory, any activity in agricultural area is subject to the regulation that 'agricultural land should not be damaged'. However, no official body has the responsibility to check whether or not a soil quarry is legitimate or not. As a result, new soil quarries (including soil quarries in agricultural land) were started to provide red soil to farmers that have olive orchards further away from Afrin's construction area.

\section{Farmers overall assessment of soil applications compared} with alternative measures

The CBA assessed under which conditions applying soil is profitable. Yet, farmers' decision is not only based on the profitability of an individual strategy but also on the availability of alternative management strategies that are also profitable and may be considered even better. The most common land management measures for hillslope orchards on shallow soil were compared by farmers via a matrix scoring exercise (Table III). The considered measures were manure application, fertilization, soil application, irrigation and the construction of terraces. Standard orchard management practices (tillage, pruning, removing new shoots) were not included in the exercise, as these are common practices conducted by almost all farmers. The criteria for evaluation of the measures were proposed by the participating farmers: effect on yield, compatibility with standard orchard management, investment cost, erosion control and social pressure or prestige.

There was consensus among farmers that for increasing olive yield in the long term, the best option is to build terraces, followed by the application of soil and manure. Farmers believe that soil application increases yields by increasing soil depth and the increase in nutrients from applying nutrient-rich red soil. Farmers unanimously reported that when red soil is applied on to the white soils, the trees look 'healthier' (darker green leaves), grow better and produce

Table III. Matrix scoring by farmers of possible land management measures for orchards on hillslopes

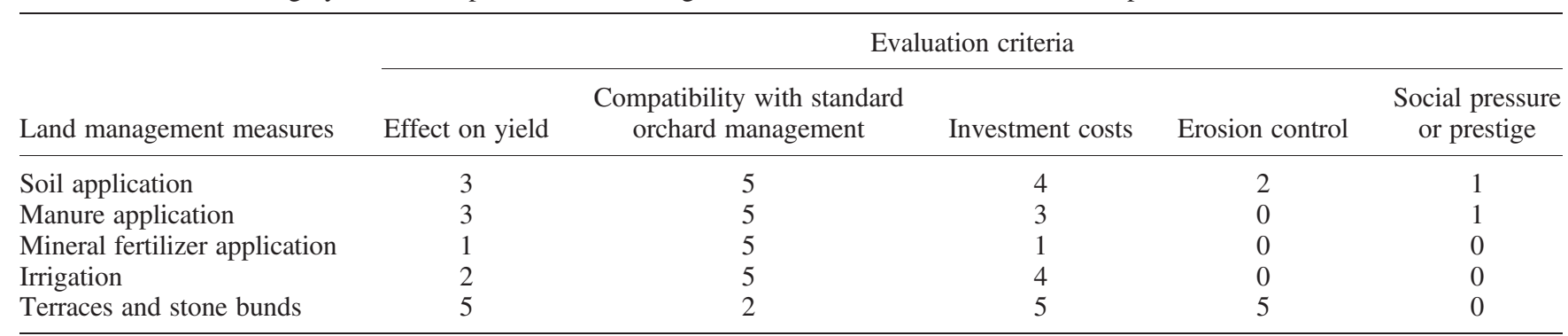

0 , no effect; 1 , very low/small; 2 , low/small; 3 , intermediate; 4 , high/large; 5 , very high/large.

Mean of scores from five group exercises. 
more and larger fruits. The effect of soil application on yield was reported not to be immediate, but most farmers did expect a considerable increase in yield in the first bearing year after having applied soil. The soil analysis revealed that the belief that the applied soil is more nutrient-rich than the original soil is not entirely correct. As Cools et al. (2003) showed for the same region, farmers' assessment of red soils being more nutrient rich is correct for red topsoils. However, the soil that is applied around the trees usually comes from deeper sediment layers (quarries can be up to $6 \mathrm{~m}$ deep) and therefore contains less nutrients.

In contrast to terraces, soil application is also compatible with the conventional tillage operations, requires no expensive manual labour and requires much less investment costs than terraces, which are considered prohibitively expensive for almost all famers. The fact that soil applications can be applied tree by tree (in contrast to terraces) and the fact that timing of application is not crucial allows to spread the investment cost over different years. It allows the farmer to apply soil when he has some money available and some free days left (for those farmers transporting the soil themselves). Some farmers claim that applying the more heavy red soil reduces erosion and hence also ensures a long-term benefit, whereas other farmers do not believe so.

None of the land management strategies in the matrixscoring exercise were perceived to be subject to strong social pressure, although some form of social prestige was reported for manure application and soil application, in the sense that these strategies are easily visible in the field and may show the farmers' innovativeness or financial means to invest in his olive orchard.

On the basis of all these criteria, farmers considered soil application and manure application as the most favourable practices for sloping orchards. This was indeed reflected by the high adoption rates of these two measures, as observed in the fields. Especially for extremely degraded orchards, soil application is considered the preferred option. On such sites, application of mineral fertilizer is of little use and establishing terraces is too expensive and is often considered no option as there is little or no soil left to conserve. The group discussion revealed that the fact that soil applications allows for a reversal in the trend of decreasing soil depth also played an important role in farmers' positive assessment of the practice, in contrast to most land conservation measures that try to stop erosion and can at best only maintain a status quo.

\section{Socio-economic determinants of adoption}

Even in villages where the practice of red soil application is found to be highly profitable, not all farmers have effectively adopted the practice. There are early adopters, late adopters and farmers who most likely will never adopt the practice.

Regression analysis of the determinants of adoption (column 1 of Table IV) shows that the most important determinants of adoption are distance to the city of Afrin (where most soil comes from because of construction activities), accessibility of the orchard via a paved or gravel road
Table IV. Regression analysis of the determinants of adoption

\begin{tabular}{lcc}
\hline Determinant of adoption & $\begin{array}{c}\text { Farmer is } \\
\text { adopter/ } \\
\text { nonadopter }\end{array}$ & $\begin{array}{c}\text { Number of } \\
\text { years since } \\
\text { first adoption }\end{array}$ \\
\hline Age & $0 \cdot 019$ & $0 \cdot 001$ \\
Age squared & $-0 \cdot 000$ & $0 \cdot 000$ \\
City-based $(1 / 0)$ & $-0 \cdot 013$ & $-0 \cdot 356^{*}$ \\
Transporter $(1 / 0)$ & $0 \cdot 167^{* * *}$ & $0 \cdot 671^{* * * *}$ \\
Field near road $(1 / 0)$ & $0 \cdot 322^{* * *}$ & $0 \cdot 080$ \\
Distance to city Afrin $(\mathrm{km})$ & $-0 \cdot 008^{* *}$ & $0 \cdot 001$ \\
Soil depth orchard $(\mathrm{cm})$ & $-0 \cdot 003^{* * * *}$ & $-0 \cdot 002$ \\
Share olives in total income $(\%)$ & $0 \cdot 002^{*}$ & $0 \cdot 001$ \\
Poor $(1 / 0)$ & $-0 \cdot 347^{* * * * *}$ & $-0 \cdot 477$ \\
Rich $(1 / 0)$ & $0 \cdot 150$ & $-0 \cdot 095$ \\
Observations & 111 & 58 \\
\hline
\end{tabular}

${ }^{a}$ Estimated partial effect of each determinant on the probability of adoption (farmer is adopter/nonadopter; based on a regression analysis using a probit model estimated by maximum likelihood procedure).

${ }^{\mathrm{b}}$ The number of years since first adopted red soil application (based on a regression analysis using a linear regression model estimated by ordinary least squares)

$* p<0 \cdot 15, * * p<0 \cdot 10, * * * p<0.05, * * * p<0.01$.

and whether the farmer works as a transporter himself. An increase in the distance to the city Afrin by $1 \mathrm{~km}$ is estimated to reduce the probability that the farmer adopt the practice by $0.8 \%$. When the farmer's orchard is located next to the road, it is $32 \%$ more likely that red soil is applied, and a farmer who works as a transporter himself is $16.7 \%$ more likely to apply soil. We also found that the probability of adoption increases with the age of the farmer whereas decreasing again for the very old farmers. The higher the share of olives in farmers' total income, the more likely the farmer will adopt the practice. In terms of wealth categories, it is found that poor farmers are much less likely to adopt the practice.

Column 2 shows which characteristics determine early or late adoption. Farmers not living in the village (but mostly in the city Aleppo) adopted the practice on average 4 months later than village-based farmers. Farmers working as a transporter adopted the practice 8 months earlier compared with other farmers.

\section{DISCUSSION}

\section{Biophysical Sustainability}

As olive yields are found to increase with $40 \%$ after soil applications, the main question is what the likely reason is for this surge in yields? The degraded olive orchards had an average soil thickness of only $0 \cdot 10 \mathrm{~m}$. The olive roots in such plots have a very limited volume to trap water and nutrients. In the case of soil addition, an increase in soil volume depth will have an immediate effect on the water-holding capacity. Also, additional nutrients are added (mainly K), but whether the newly added nutrients will immediately become available for the olive tree will depend on the nutrient dynamics in the soil, the root distribution and soil moisture.

A number of studies suggest that a higher volume of available water contained in the soil and a higher potassium content can result in a rapid yield response. Studies focusing 
on water use in olive cultivation found that reducing the water deficit (especially early in the season) strongly increases yields and that this effect occurs already in the first years after treatment (Iniesta et al., 2009; Correa-Tedesco et al., 2010; Palese et al., 2010). K deficiency is described as one of the most important nutritional problems for olive cultivation, causing important symptoms of dehydration (Fernández-Escobar et al., 1994), and olive trees respond rapidly to increased $\mathrm{K}$ application (Restrepo-Diaz et al., 2008). For our study area, Tubeileh et al. (2008) found that $77 \%$ of the yield variations between olive trees in Afrin is explained by the amount of soil potassium and soil depth, which are two factors that we found to be largely increased by applying red soil.

Although we have no data on the effect of the soil applications on the nutrient dynamics in the soil and the plant responses, it is reasonable to assume, on the basis of our data and the existing literature, that olive yield was increased by the improved soil water-holding capacity and potassium content. Nitrogen and phosphorus could be secondary explanatory factors.

Hence, besides adding nutrients, the applied soil acts like a mulch in that it affects crop yield in the first place by contributing to the conservation of soil water and the adsorption of nutrients. Mulches of stone, organic or synthetic material are used in many places to protect the soil or plant against erosion or evaporation or to increase water and nutrient availability (Poesen et al., 1994; Mulumba \& Lal, 2008; Smets et al., 2008; Alegre Prats et al., 2013; Jiménez et al., 2013). Especially if the soil comes from deep nutrient-poor horizons, it is this mulching effect rather than the addition of nutrients that explains the increase in olive yield. An additional explanation for the positive effect on olive yield from applying soil originating from such deep horizons may result from the fact that these sediments contain no seeds, leading to a lower weed competition compared with topsoil.

However, a major concern is how long the increase in soil nutrients, soil depth and water-holding capacity and their effect on olive yield will last. Even though the newly added soil will protect the original surface soil at least to some extent from erosion by providing a mulch cover, it is not clear whether the newly added red soil itself will erode more or less rapidly compared with the original soil. After the red soil is applied, usually no measures are taken to conserve the newly applied soil, and the erosive tillage operations are continued as before. Barneveld et al. (2009) estimated an annual decrease of soil depth of $7 \mathrm{~mm}$ on $25 \%$ slopes under frequent tillage passages, which would mean that the applied soil is lost completely after 12 years' time. If the loosely added red soil erodes more easily, the applied soil will disappear even faster. As a result, the practice of soil application will even increase the volume of eroded soil and the deposit of soil sediments downhill, clogging up roads and waterways. Especially when soil is taken from fertile agricultural lands, the practice of soil application induces the loss of additional soil resources through the quarrying of soil in agricultural valley bottoms.
Finally, the practice of soil application involves some risks that very little farmers seem to be aware of. First, the practice may enhance the spread of the pathogen Verticillium Wilt (Verticillium dahliae Kleb.), which blocks the vascular tissues of the tree leading to reduced water and nutrient flows, reduced olive yields and eventually to the death of the tree. This disease can survive in the soil or roots for more than 15 years, is very difficult to suppress and is more prevalent in the humid valley-bottom orchards than on the hillslopes (Al-Ahmad \& Mosli, 1993). Quarrying and applying valley-bottom soil may spread the disease over very large areas of hillslope orchards. A second risk is related to the fact that some farmers started experimenting with applications of household rubbish ashes and garbage to their olive trees, as an alternative to the practice of soil application. Although these ashes certainly contain useful nutrients, they may also contain heavy metals and other harmful constituents. This demonstrates that scientists can play an important role in rigorously identifying the risks that local practices may bring in the long term and on a large scale, while policy makers have an important role to play in regulating the use of land resources beyond the farm level in order to ensure the sustainable use of land at a regional scale.

\section{Economic and Social Sustainability}

Our findings suggest that soil application is - at least in the short run and given the contextual factors at the time of research - an economically profitable investment for orchards located in the vicinity of a soil quarry. The favourable context of high olive prices, cheap fuel and the abundance of cheap and available soil allowed farmers to experiment with red soil applications.

These contextual factors contributed importantly to the profitability of applying soil at the time of research, but they are continuously changing and may alter the future profitability of the practice. In the meantime, the Syrian government gradually reduced fuel subsidies, and by 2008, fuel prices in Syria had more than doubled (Reuters, 2008), rendering the transportation of soil much more costly. As a result, the application of red soil may have become unprofitable in more distant places. The construction activity in Afrin may also be susceptible to large fluctuations, and if the number of new buildings decreases, the supply of soil will largely dry up. As long as no clear regulation is developed and implemented, the soil from construction sites may eventually be increasingly substituted by soil from quarries in agricultural land, leading to a further loss of fertile soil. It is not clear what will happen to these quarries once quarrying has stopped but is likely that they will gradually transform into ponds.

Economic profitability is a prerequisite for adoption, but there are many other factors that determine farmers' adoption or nonadoption of soil and water conservation techniques. Farmers' awareness of the erosion problem and their ability and willingness to undertake measures are crucial phases in the adoption process (e.g. de Graaff et al., 2008; Wildemeersch et al., 2013). 
Although two-thirds of farmers in our study area link declining yields to erosion (Hoorelbeke, 2005), farmers with fields with more shallow soils are likely better aware and take the erosion problem more serious. The same holds for farmers that derive a larger share of their income from their olive orchards and farmers living in the villages, compared with city-based farmers. Our results indeed show that citybased farmers are also adopting the practice but later than farmers that are based in the villages. In line with earlier studies (de Graaff et al., 2008), farmers earning a higher share of their income off-farm are less likely to adopt the practice, as other off-farm activities may receive priority.

With respect to the wealth class of farmers who adopted the practice of red soil application, it is found that the poorest farmers are much less likely to adopt. They probably lack the means to invest, not only for red soil application but also for most other land management techniques. On the other hand, the fact that the investment of soil applications can be spread over several years allows also less wealthy farmers, which may face difficulties in making large investments at a time, to adopt the practice. Not only the rich but also resident farmers of the medium wealth category are found to be able to adopt the practice, especially when olive farming makes up a large share of their income and when they dispose of transport equipment themselves. Given these socio-economic determinants of adoption, it seems that the group of potential adopters is rather broad and that the number of adopters may further increase if soil remains cheaply available and the market and institutional context continue to be favourable.

A final concern relates to the fact that the rapidly growing group of interested farmers that are able and willing to pay for red soil resulted in an increased demand for soil, and because of the lack of regulation, some farmers started to quarry (and sell) soil from their own orchards. A number of poor farmers started to quarry and sell soil from their orchards to pay off debts. If this type of soil quarries becomes more widespread, as a fast but short-term solution to earn cash, the practice of red soil application may de facto consist of the transfer of soil from the poorest to the more well-off olive farmers in the region. This will have severe long-term consequences on the capacity of these poor households to escape poverty via agriculture.

The fast adoption of the soil application practice proves that when a practice is well adapted to the local needs, compatible with common land husbandry practices and profitable within a relatively short period, farmers of different wealth categories respond very fast. Also, the fact that this practice allows for restoring and not only stopping soil degradation certainly favoured its adoption. This underlines the need for understanding the actual decision criteria that are used by farmers, when the introduction of new conservation measures is considered.

\section{CONCLUSIONS}

Our analysis of the local soil restoration technique by applying soil in NW Syria shows that applying red clayey valley-bottom soil onto white heavily eroded soils of hillside olive orchards improves olive yield by about $40 \%$ on average. This yield increase can mainly be attributed to the increase of soil depth by $36 \%$, soil water availability by $28 \%$ and total available soil nutrients, that is, potassium $(+45 \%)$, nitrogen $(+12 \%)$ and phosphorus $(+6 \%)$. The socio-economic analysis confirmed that the practice is economically viable and adopted by a wide range of farmer types.

Although applying soil is found to be biophysically and economically sustainable at the individual farm level and in the short run, there are serious concerns regarding the sustainability of this practice in the long term and at the regional scale.

Note that one needs to be cautious when extrapolating these findings to other regions, because impacts on olive yields, costs and overall sustainability depend largely on contextual factors. Nevertheless, this study highlights the potential of soil applications to (temporary) reverse soil degradation and to restore olive yield levels. If the practice of applying red soil could be combined with soil conservation measures that can keep the new soil in situ, it could become a crop yield-increasing and sustainable technique. By allowing incomes to increase significantly in the short run, rather than to halt a gradual continuous decline in the revenues from olive farming, applying soil may provide the necessary incentive to stimulate the adoption of conservation measures. Although avoiding soil degradation remains in the first place more desirable, the combination with soil restoration may be an interesting path to consider in the future development of soil conservation measures for areas with advanced stages of soil degradation.

\section{ACKNOWLEDGEMENTS}

The authors wish to thank ICARDA and its staff for logistic support, scientific advice and soil sample analyses; Nadia Salem for assistance during the field work and all farmers in Afrin district for their willingness to participate. We acknowledge the valuable assistance of Ward Colen and Eline Vanuytrecht and the financial support from VLIR-UOS and Research Foundation Flanders (FWO). We are also grateful to the reviewers and to Artemio Cerdá for their valuable comments and suggestions that greatly improved the article.

\section{REFERENCES}

Al-Ahmad MA, Mosli MN. 1993. Verticillium wilt of olive in Syria. EPPO Bulletin 23: 521-529.

Alegre Prats S, Cortizo Malvar M, Simões Vieira DC, MacDonald L, Keizer JJ. 2013. Effectiveness of hydromulching to reduce runoff and erosion in a recently burnt pine plantation in central Portugal. Land Degradation \& Development. DOI: 10.1002/ldr.2236

Barneveld RJ, Bruggeman A, Sterk G, Turkelboom F. 2009. Comparison of two methods for quantification of tillage erosion rates in olive orchards of north-west Syria. Soil and Tillage Research 103: 105-112.

Bremmer JM, Mulvaney CS. 1982. Nitrogen total. In Methods of soil analysis. Part 2, Page AL, Miller RH, Keeney DR (eds). American Society of Agronomy: Madison, WI; 595-624. 
Brenot J. 2007. Quantification de la dynamique sédimentaire en context anthropisé. L'érosion des versants viticoles de Côte-d'Or, PhD. Thesis. Université de Bourgogne - Centre des Sciences de la Terre, Dijon, France.

Bruggeman A, El-Naeb H, Masri Z, Turkelboom F, Zöbisch M. 2005. Land management strategies to sustain productivity of olive groves on steep slopes in northwestern Syria. FAO Land and Water Bulletin 10. FAO, Rome: $75-87$.

Cerdà A, Lavee H, Romero-Díaz A, Hooke J, Montanarella L. 2010. Soil erosion and degradation on Mediterranean type ecosystems: preface. Land Degradation \& Development 21: 71-74. DOI: 10.1002/ldr.968

Colen L, Van Steenwinkel S. 2007. Soil transfers in olive orchards of NW Syria. A biophysical and socio-economic analysis of a local innovation. MSc. Thesis. Faculty of Bioscience Engineering, KU Leuven, Belgium.

Cools N, De Pauw E, Deckers J. 2003. Towards an integration of conventional land evaluation methods and farmers' soil suitability assessment: a case study in northwestern Syria. Agriculture, Ecosystems and Environment 95: 327-342.

Correa-Tedesco G, Rousseaux MC, Searles PS. 2010. Plant growth and yield responses in olive (Olea europaea) to different irrigation levels in an arid region of Argentina. Agricultural Water Management 97: 1829-1837.

Critchley WRS, Reij CP, Willcocks TJ. 1994. Indigenous soil and water conservation: a review of the state of knowledge and prospects for building on traditions. Land Degradation \& Development 5: 293-314.

De Pauw E, Masri Z, Shimizu T. 2006. Description of soil profile TALAF colluvium olive orchard. ICARDA: Aleppo, Syria.

Esri.2009. World Terrain Base, http://server.arcgisonline.com/ArcGIS/rest/ services/World_Terrain_Base/MapServer

Fernández-Escobar R, García-Barragán T, Benlloch M. 1994. Estado nutritivo de las plantaciones de olivar en la provincial de Granada. ITEA 90: $39-49$.

Gebreyohannes G, Nyssen J, Poesen J, Bauer H, Merckx R, Haile M, Deckers J. 2012. Land reclamation using reservoir sediments in Tigray, northern Ethiopia. Soil Use and Management 28: 113-119.

de Graaff J, Amsalu A, Bodnár F, Kessler A, Posthumus H, Tenge A. 2008. Factors influencing adoption and continued use of long-term soil and water conservation measures in five developing countries. Applied Geography 28: 271-280

He X, Yibei X, Zhang X. 2007. Traditional farming system for soil conservation on slope farmland in southwestern China. Soil and Tillage Research 94: 193-200.

Hoorelbeke S. 2005. Impact of land use on land degradation in the hilly olive orchards of NW Syria. MSc. Thesis. Faculty of Bioscience Engineering, KU Leuven, Belgium.

Iniesta F, Testi L, Orgaz F, Villalobos FJ. 2009. The effects of regulated and continuous deficit irrigation on the water use, growth and yield of olive trees. European Journal of Agronomy 30: 258-265.

Jiménez MN, Fernández-Ondoño E, Ripoll MA, Castro-Rodríguez J, Huntsinger L, Navarro FB. 2013. Stones and organic mulches improve the Quercus ilex L. afforestation success under Mediterranean climatic conditions. Land Degradation and Development. DOI: 10.1002/ ldr. 2250

Knudsen D, Peterson GA, Pratt PF. 1982. Lithium, sodium, and potassium. In Methods of soil analysis. Part 2, Page AL, Miller RH, Keeney DR (eds). American Society of Agronomy: Madison, WI; 225-246.

Li XY. 2003. Gravel-sand mulch for soil and water conservation in the semiarid region of northwest China. Catena 52: 105-127.

McDonald M, Brown K. 2000. Soil and water conservation projects and rural livelihoods: options for design and research to enhance adoption and adaptation. Land Degradation \& Development 11: 343-361. DOI: 10.1002/1099-145X(200007/08)11:4<343::AID-LDR397>3.0.CO;2-Z

Milgroom J, Gómez JA, Soriano MA, Fereres E. 2007. From experimental research to an on-farm tool for participatory monitoring and evaluation: an assessment of soil erosion risk in organic olive orchards. Land Degradation \& Development 18: 397-411. DOI: 10.1002/ldr.783

Mulumba LN, Lal R. 2008. Mulching effects on selected soil physical properties. Soil and Tillage Research 98: 106-111.
Nachtergaele J, Poesen J, van Wesemael B. 1998. Gravel mulching in vineyards of southern Switzerland. Soil and Tillage Research 46: 51-59.

Nelson DW, Sommers LE. 1982. Total carbon, organic carbon, and organic matter, In Methods of soil analysis. Part 2, Page AL, Miller RH, Keeney DR (eds). American Society of Agronomy: Madison, WI; 539-579.

Nyssen J, Haile M, Moeyersons J, Poesen J, Deckers J. 2000. Soil and water conservation in Tigray (northern Ethiopia): The traditional Daget technique and its integration with introduced techniques. Land Degradation \& Development 11: 199-208. DOI: 10.1002/1099-145X(200005/06) 11:3<199::AID-LDR376>3.0.CO;2-Y

Olsen SR, Cole CV, Watanabe FS, Dean LA. 1954. Estimation of available phosphorus in soil by extraction with sodium bicarbonate. U.S. Dep. Agric. Circ. 939: USA.

Palese AM, Nuzzo V, Favati F, Pietrafesa A, Celano G, Xiloyannis C. 2010. Effects of water deficit on the vegetative response, yield and oil quality of olive trees (Olea europaea L., cv Coratina) growth under intensive cultivation. Scientia Horticulturae 125: 222-229.

Papiernik S, Schumacher T, Lobb D, Lindstrom M, Lieser M. 2009. Soil properties and productivity as affected by topsoil movement within an eroded landform. Soil \& Tillage Research 102: 67-77.

Pérez y Pérez L, Barreiro-Hurlé J. 2009. Assessing the socio-economic impacts of drought in the Ebro River Basin. Spanish Journal of Agricultural Research 7: 269-280.

Poesen J, Torri D, Bunte K. 1994. Effects of rock fragments on soil erosion by water at different spatial scales: a review. Catena 23: 141-166.

Reed MS, Fazey I, Stringer LC, Raymond CM, Akhtar-Schuster M, Begni G, Bigas H, Brehm S, Briggs J, Bryce R, Buckmaster S, Chanda R, Davies J, Diez E, Essahli W, Evely A, Geeson N, Hartmann I, Holden J, Hubacek K, Ioris AAR, Kruger B, Laureano P, Phillipson J, Prell C, Quinn CH, Reeves AD, Seely M, Thomas R, Van Der Werff Ten Bosch MJ, Vergunst P, Wagner L. 2013. Knowledge management for land degradation monitoring and assessment: an analysis of contemporary thinking. Land Degradation \& Development 24: 304-322.

Restrepo-Diaz H, Benlloch M, Navarro C, Fernández-Escobar R. 2008 Potassium fertilization of rainfed olive orchards. Scientia Horticulturae 166: $399-403$

Reuters. 2008. Syria raises gasoline prices, March 24, 2008. http://in reuters.com/article/2008/03/24/syria-gasoline-idINL2452943720080324

Scherr S. 1999. Soil degradation. A threat to developing-country food security by 2020 ? Food, Agriculture and the Environment Discussion Paper 27. IFPRI, Washington DC.

Smets T, Poesen J, Knapen A. 2008. Spatial scale effects on the effectiveness of organic mulches in reducing soil erosion by water. Earth-Science Reviews 89:1-12.

Tejedor M, Jiménez C, Diaz F. 2003. Volcanic materials as mulches for water conservation. Geoderma 117: 283-295.

Torri D, Poesen J, Borselli L. 1997. Predictability and uncertainty of the soil erodibility factor using a global dataset. Catena 31: 1-22.

Tubeileh A, Turkelboom F, Abdeen M, Jameel M, Abdallah I, Sultan-Tubeileh K. 2008. How do soil conditions affect olive productivity in hilly areas of north-western Syria? International Center for Agricultural Research in the Dry Areas (ICARDA), Aleppo, Syria. Internal report, $18 \mathrm{p}$.

Van Bemmelen JM. 1890. Über die bestimmung des wassers, des humus, des schwefels, der in den colloïdalen silikaten gebundenen kieselsäure, des mangans u.s.w. im ackerboden. Die Landwirthschaftlichen VersuchsStationen 37: 279-290.

Vogt J. 1970. Aspects de l'érosion historique des sols en bourgogne et dans les régions voisines. Annales de Bourgogne 42: 30-50.

Wildemeersch JCJ, Timmerman E, Mazijn B, Sabiou M, Ibro G, Garba M, Cornelis W. 2013. Assessing the constraints to adopt water and soil conservation techniques in Tillaberi, Niger. Land Degradation \& Development. DOI: $10.1002 / \mathrm{ldr} .2252$

WRB (IUSS Working Group). 2006. World reference base for soil resources 2006. World Soil Resources Reports No. 103. FAO, Rome.

Zdruli P. 2012. Land resources of the Mediterranean: status, pressures, trends and impacts on future regional development. Land Degradation \& Development. DOI: 10.1022/ldr.2150. 